\title{
Jolanta Maćkiewicz
}

Uniwersytet Gdański

\section{Więcej niż tysiąc słów. Perswazyjne działanie zdjęć prasowych}

\author{
Streszczenie \\ W artykule podjęto kuestię przekazów multimodalnych o funkcji persuazyjnej. Skoncentrowano \\ się na perswazyjnej roli elementów obrazowych, a ściślej rzecz ujmując zdjęć. Źródłem przykładów \\ była „Polityka”. Analiza czterech przykładów pokazuje, że zdjęcia nie tylko przyciągają uwagę \\ i pobudzają emocje, lecz także uspółtworzą i wzmacniają argumentację.
}

Słowa kluczowe: multimodalność, fotografia, perswazja, argumentacja.

\section{More than thousand words. Persuasive function of iconic elements}

\section{Abstract}

The article is dealing with the problem of multimodal messages with persuasive function. It is concentrated on the role of iconic elements, and more specifically - photographs, in persuasion. The weekly „Polityka” was the source of examples. The analysis of the four examples shows that photographs not only attract attention and affect emotions but co-create and strengthen argumentation as well.

Keywords: multimodality, photographs, persuasion, argumentation.

Jeden obraz wart/uyraża więcej niż tysiąc słów. (przysłowie chińskie)

Najważniejszą zmianą dostrzeganą w praktykach komunikacyjnych ostatnich dziesięcioleci jest uciąż rosnąca rola komunikatów wielokodowych, czyli wykorzystujących róunocześnie kilka systemów semiotycznych. Oczywiście, komunikaty wielokodowe, czyli polisemiotyczne, nie są niczym nowym. Jak zauważył Kazimierz Michaleuski: „komunikat składający się wyłącznie ze znaków językowych - mógł się właściuie objawiać wyłącznie w telegraficznym przekazie dokonywanym z użyciem alfabetu Morse'a" ${ }^{1}$. Nowością jest to, że poustają wciąż nowe mieszane formy komunikacji i że słowo (pisane czy mówione) nie musi odgrywać u nich najistotniejszej roli. Coraz istotniejszą rolę w komunikacji odgrywają natomiast znaki obrazowe (ikoniczne). W związku z tym mówi się o tak zwanym. zurocie ikonicznym, piktorialnym czy wizualnym (pictorial/visual/iconic turn), który „trzeba rozumieć jako różnie kierunkowaną refleksję

\footnotetext{
${ }^{1}$ K. Michaleuski, Komunikaty mieszane, Wydaunictwo Uniwersytetu Łódzkiego, Łódź 2009, s. 9.
} 
nad obszarem kultury wizualnej, społeczno-kulturowymi przejawami wizualności i sposobami jej percepcji”2. Jak zauważa Agnieszka Kampka: „[...] zmiana polega nie tylko na uszechobecności obrazu, ale także na dostrzeżeniu, że nie jest on aktorem drugiego planu, zrozumieniu, w jak wielkim stopniu poprzez oddziaływanie na nasze myślenie, pobudzanie emocji, budowanie pamięci obraz upływa na kształt rzeczywistości”3.

Wciąż rosnąca komunikacyjna rola obrazów wiąże się z tym, że znaki ikoniczne mogą pełnić wszelkie funkcje pełnione przez znaki językowe: od funkcji informacyjnej po persuazyjną. Mogą je pełnić samodzielnie lub - najczęściej - w powiązaniu z werbalnymi komponentami multimodalnego komunikatu (także - chociażby w przekazach telewizyjnych - w powiązaniu z elementami muzycznymi i innymi dźwiękowymi). W tym artykule skupię się na jednej z funkcji, tej, która jest uważana - obok informacyjnej - za najistotniejszą dla międzyludzkiej komunikacji, czyli na funkcji perswazyjnej.

Zastanóumy się zatem, w jaki sposób elementy ikoniczne mogą pełnić funkcję persuazyjną.

Persuazja, czyli nakłanianie pośrednie, to takie działanie komunikacyjne, które ma na celu zmianę postaw odbiorców. Na to perswazyjne działanie składa się racjonalna, logiczna argumentacja oraz - zazwyczaj - elementy dodatkowe: oddziaływanie na emocje, budzenie skojarzeń, odwołania do „miejsc uspólnych” (symboli kulturowych, stereotypów...), do poglądów, doświadczeń, oczekiwań audytorium. Warunkiem koniecznym do zainaugurowania oddziaływań perswazyjnych jest nawiązanie kontaktu z odbiorcą, przyciągnięcie go, zainteresowanie przekazem. Gdy już zostanie to osiągnięte, nadawca na różne sposoby stara się ukierunkować odbiór, zasugerować takie ramy interpretacyjne, które by służyły najlepiej osiągnięciu perswazyjnego celu.

Jak w tę działalność wpisują się elementy ikoniczne?

Niewątpliwie obrazy pełnią funkcję przyciągającą. W komunikacie słowno-obrazouym - czy będzie to reklama, czy pierusza strona gazety, czy wiadomości telewizyjne - najpierw (co udowodniły badania) zuracamy uwagę na obraz. W dodatku róunież te słowa, które są upisane w obraz, graficznie z nim zintegrowane, na przykład nagłówek czy lid umieszczony na fotografii prasowej, zuracają na siebie większą uwagę.

Poza tym obrazy, z czym róunież uszyscy badacze się zgadzają, silniej niż słowa oddziałują na emocje. Oddziałują poprzez swoją żywość (vividness ${ }^{4}$ ) i wyrazistość. Działają przy tym szybciej niż słowa, ponieważ ich odbiór jest symultaniczny, całościouy, nie zaś linearny.

W dodatku - jako przekaz z natury polisemiczny, skondensowany, gęsty semiotycznie - obrazy niosą bogactwo treści, zawierają wiele mniej czy bardziej skonwencjonalizowanych konotacji. Dzięki temu budzą rozmaite skojarzenia oraz są w stanie dotrzeć do rozmaitych typów odbiorców o różnej kompetencji wizualnej i różnych doświadczeniach.

\footnotetext{
${ }^{2}$ B. Skowronek, Mediolingwistyka. Wprowadzenie, Wydawnictwo Naukowe Uniwersytetu Pedagogicznego, Kraków 2013, s. 100.

3 A. Kampka, Retoryka wizualna. Perspektywy i pytania, „Forum Ars Rhetoricae” 2011, nr 1, 10.

${ }^{4}$ Zob. Ch.A. Hill, The psychology of rhetorical images [w:] Defining Visual Rhetorics, red. Ch.A. Hill, M.Helmers, Lawrence Erlbaum Associates, Inc. Mayham 2004.
} 
Jak podkreśla Agnieszka Kampka: „obraz ożywia przekaz, pozwala unaocznić abstrakcję [...]. Obraz może być perswazyjny, nie będąc argumentem. Jednocześnie zaś służy argumentacji - dodając jej dramatyzmu i siły poprzez możliwość odwołania się do kulturowych ikon, powszechnie podzielanych symboli" ${ }^{\prime}$.

Centrum działań perswazyjnych jest zazwyczaj argumentacja. I tu pojawia się pytanie: czy i u jaki sposób elementy ikoniczne mogą służyć argumentacji? Czy możliue są argumenty czysto wizualne, czy też zawsze obraz musi występować w powiązaniu z elementami werbalnymi? A jeśli weźmiemy pod uwagę argumentację heterogeniczną, werbalno-ikoniczną, to czy elementy ikoniczne tylko ilustrują argumentację słouną lub jej towarzyszą, czy też odgrywają (jakąś - jaką?) istotniejszą rolę?

Pominę pieruszą kuestię dotyczącą możliwości istnienia argumentów jedynie wizualnych, ponieważ badane przeze mnie przekazy medialne zausze mają charakter heterogeniczny, a najistotniejsza jest w nich relacja między obrazem a słowem (choć i dźwięki w relacjach radiowych czy telewizyjnych mogą odgrywać znaczącą rolę). Skupię się zatem na tym, jak funkcja perswazyjna (w tym: argumentacja) jest pełniona przez powiązane ze sobą obrazy i słowa.

George Roque wyróżnia cztery możliwe perswazyjne funkcje elementów wizualnych uspólistniejących w przekazie z elementami werbalnymi:

- visual flag (wizualna flaga, chorągiewka) - kiedy element obrazouy służy wyłącznie przyciągnięciu uwagi;

- paralel argument (argument paralelny) - kiedy element wizualny i werbalny prezentują ten sam argument;

- joint argument (argument łączony) - kiedy element wizualny i werbalny łączą się dla stworzenia jednego argumentu;

- contrasting argument - kiedy element wizualny i werbalny kontrastują ze sobą, aby stuorzyć jeden argument ${ }^{6}$.

Wydaje się, że najciekauszą możliwością jest ta trzecia (argument łączony), wynika ona bowiem z samej istoty multimodalnego komunikatu. Jak bowiem pisał Bogusław Skowronek o polisemiotycznych z natury komunikatach medialnych: „Medialne treści nie są prostą sumą narracji obrazowej, dźwiękowej i słownej, tylko efektem ich wzajemnego przenikania i oddziaływania - procesem transsemiotycznym"? Połączenie elementów wizualnych i werbalnych oznacza ich wzajemne wpływanie na siebie, wzajemną kontekstualizację, dynamiczną interakcję. Co istotne, ułaśnie używanie przekazu wielokodowego wpływa na wzmocnienie funkcji perswazyjnej. Z jednej bowiem strony odbiorca jest mniej odporny na równoczesne oddziaływanie dwóch czy więcej systemów semiotycznych, z drugiej zaś tak jak mówi się, że globalny sens

\footnotetext{
${ }^{5}$ A. Kampka, op. cit., s. 16.

${ }^{6}$ G. Roque, Visual argumentation: a further reappraisal [w:] Topical Themes in Argumentation Theory: Twenty Exploratory Studies, red. F.H. van Eemeren, B. Garssen, Springer Netherlands, Amsterdam 2012, s. 273-288.

${ }^{7}$ B. Skouronek, op. cit., s. 96.
} 
komunikatu polisemiotycznego ma charakter multiplikatywny, nie zaś sumaryczny, podobnie charakter multiplikatywny, nie zaś sumaryczny ma jego moc perswazyjna.

Swoją funkcję perswazyjną (w tym: argumentacyjną) obrazy wypełniają w różnych typach komunikatów, między innymi w komunikatach reklamowych (zamieszczanych w prasie, telewizji, internecie czy na różnego rodzaju nośnikach zeunętrznych, na przykład billboardach) oraz w komunikatach medialnych o charakterze informacyjnym czy informacyjno-publicystycznym. W tych ostatnich odnajdujemy wiele rodzajów elementów ikonicznych: od prasowej typografii nierozłącznie splecionej ze słowem, poprzez obrazy statyczne - zdjęcia, rysunki, infografikę, po dynamiczne obrazy telewizyjne. W swoim artykule ograniczę się do jednego typu przekazów ikonicznych - do fotografii, przy tym wyłącznie do fotografii znajdującej się w tygodnikach społeczno-politycznych.

To drugie ograniczenie wynika z tego, że rola fotografii jest odmienna u dziennikarskich gatunkach informacyjnych i gatunkach publicystycznych. Dotyczy to i doboru zdjęć, i ich charakteru oraz dominującej funkcji, i ich relacji ze słowem.

W tygodnikach społeczno-politycznych dobór fotografii nie musi być bezpośrednio związany z informacyjną zawartością tekstu - może to być stare zdjęcie agencyjne czy zdjęcie wzięte z zasobów internetowych. W dodatku publicystycznemu tekstowi mogą towarzyszyć nie tylko tak czy inaczej dobrane i tak czy inaczej przycięte fotografie dokumentalne. Pojawiają się zdjęcia aranżowane, kreowane, niekiedy bliskie już fotografii artystycznej. Coraz częściej występują też fotomontaże (zułaszcza na okładkach).

Odmienna jest róunież dominująca funkcja pełniona przez fotografie. W gatunkach informacujnych zdjęcie pełni głównie funkcję dokumentującą, głosi: „to się naprawdę zdarzyło i wyglądało właśnie tak". W gatunkach publicystycznych zdjęcie pełni przede wszystkim funkcję przyciągającą i perswazyjną.

Bardzo ważna jest relacja zdjęcia z towarzyszącym mu tekstem. I ona też różni gatunki publicystyczne od informacyjnych. W gatunkach publicystycznych zdjęcie nie zausze ma podpis, a jeśli już - to nie zausze jest to podpis o charakterze informacyjnym, to znaczy nie jest to podpis identyfikujący osoby, przedmioty oraz czas i miejsce wykonania zdjęcia. Zdjęcie może wchodzić ponadto u relacje z nagłówkiem i lidem artykułu. Zdjęcie i uspółdziałające z nim elementy werbalne wzajemnie się kontekstualizują i doprecyzowują, tworząc całościowy przekaz, przy czym mamy tu do czynienia ze swoistym podziałem pracy.

Jako źródło materiałów wykorzystałam jeden z funkcjonujących na rynku prasowym tygodników opinii - „Politykę”, gdzie, moim zdaniem, zdjęcia są najciekausze i najbardziej urozmaicone. Aby pokazać perswazyjną moc dziennikarskich fotografii, uybrałam do analizy zdjęcia należące do czterech różnych typów:

- fotografię dokumentalną opatrzoną podpisem;

- fotografię z istotnym użyciem środków technicznych";

- fotografię kreowaną;

${ }^{8}$ Zob. T. Piekot, Dyskurs polskich wiadomości prasowych, TAiWPN Universitas, Kraków 2006, 130-133. 
- fotomontaż.

Pominęłam zdjęcia okładkowe, okładka stanowi bowiem swoisty gatunek medialny, którym należałoby się zająć osobno.

\section{Przykłady}

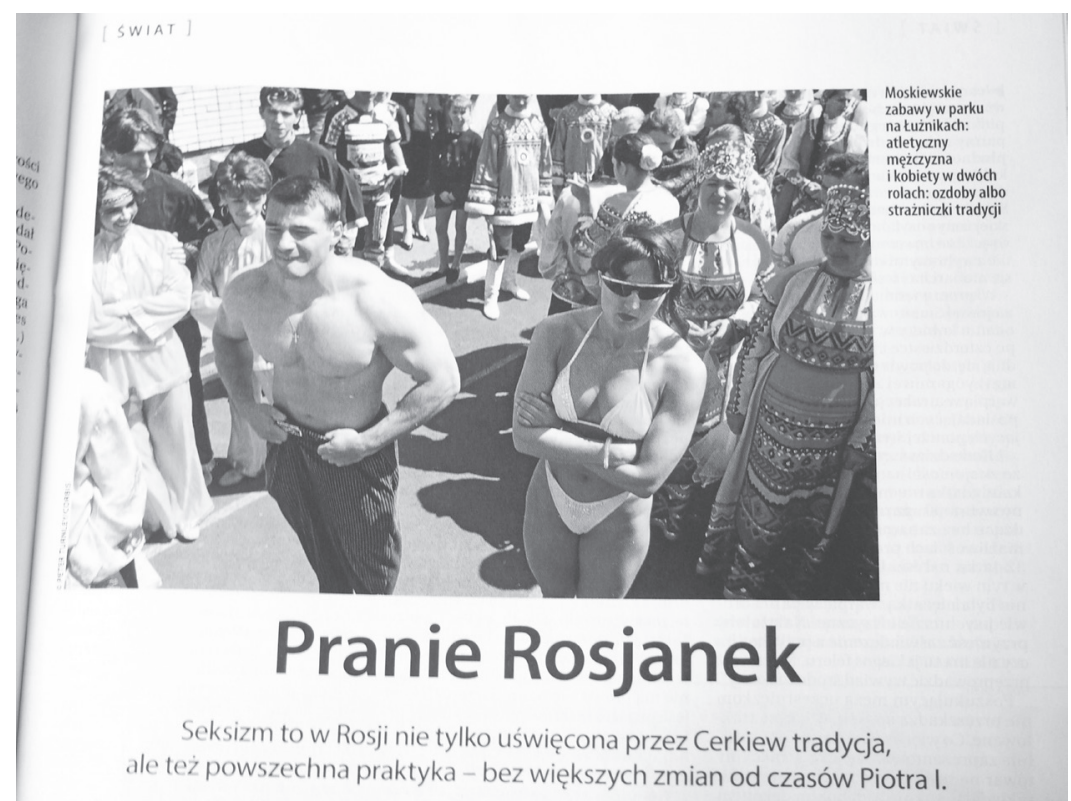

Przykład 1. Artykuł Pranie Rosjanek („Polityka” 2016, nr 15).

Zdjęcie o charakterze dokumentalnym zostało umieszczone nad nagłówkiem artykułu, a towarzyszy mu podpis: „Moskieuskie zabawy w parku na Łużnikach: atletyczny mężczyzna i kobiety w dwóch rolach: ozdoby albo strażniczki tradycji”.

Fotografia u sposób bardzo wyrazisty egzemplifikuje metonimiczny charakter wszystkich zdjęć. Chodzi nie tylko o uybór kadru, który na zasadzie „część za całość” ma informować o całym (rozciągniętym u przestrzeni i czasie) zdarzeniu. „Wewnątrz kadru poustaje odrębny świat” - podkreśla David duChemin ${ }^{9}$. „Tworzymy, zamykając wewnątrz kadru niewielkie części i sugerujemy relacje nigdy niespotykane w rzeczywistości. Odcinając uszystko, co otacza fotografowany przedmiot, kierujemy uwagę widzów na to, co mieści się w kadrze. Pokazujemy więcej, pokazując mniej”"10. Chodzi również o możliwy symboliczny uymiar prezentowanych na zdjęciu postaci czy obiektów. Znajdujący się na pieruszym planie mężczyzna - punctum tego zdjęcia

\footnotetext{
${ }^{9}$ D. duChemin, Język fotografii. Rozważania o tworzeniu mocniejszych zdjęć, tłum. W. Tkaczyński, Galaktyka, Łódź 2012, s. 17.

10 Ibidem, s. 18.
} 
(według Barthesa ${ }^{11}$ element przyciągający wzrok) - symbolizuje pewien typ mężczyzn (macho pyszniący się swoją siłą fizyczną). Również towarzyszące mu kobiety oddziałują nie poprzez denotację (kim są), lecz poprzez konotację (jakie skojarzenia wywołują). Podpis sugeruje interpretację: zgrabna dziewczyna w bikini to ozdoba, kobiety w strojach ludowych to strażniczki tradycji. Duruznaczny nagłówek (Pranie Rosjanek) jedynie informuje, o kim będzie mowa (Rosjanki) i nie wiąże się ze zdjęciem. Natomiast publicystyczny, perswazyjny charakter ma lid: „Seksizm to u Rosji nie tylko utwierdzona przez Cerkiew tradycja, ale też pouszechna praktyka - bez większych zmian od czasów Piotra I". To ułaśnie lid sprawia, że tę fotografię traktujemy jako wizualizację o charakterze symbolicznym ${ }^{12}$, która u sposób skondensowany i silniej „niż tysiąc słów" ukazuje kwestię seksizmu, wizualizuje i uwypukla główną tezę artykułu. Jak bowiem podkreśla Tomasz Piekot: „zdjęcia symboliczne są [... syntezą (streszczeniem) tekstu” ${ }^{13}$. Już na tym przykładzie widać, że zrozumienie obrazu nie polega jedynie na zrozumieniu, co on przedstawia, lecz róunież - co ma być ukazane za jego pomocą.

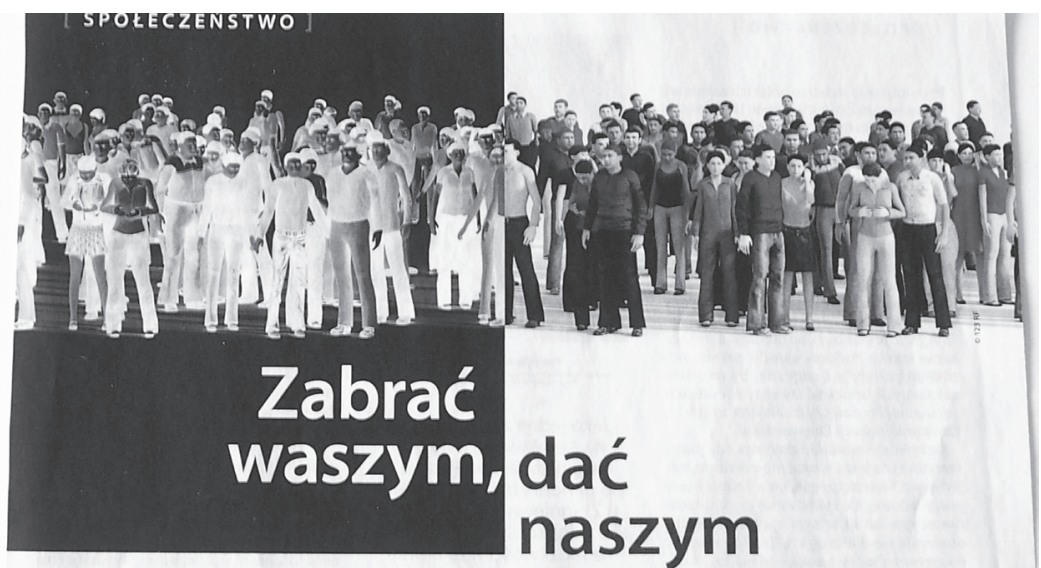

Władza chce stworzyć nowe społeczeństwo obywatelskie i czuwać nad jego rozwojem. Oznacza to ideologiczną weryfikację organizacji pozarządowych i inny klucz dzielenia publicznych pieniędzy.

Przykład 2. Artykuł Zabrać waszym, dać naszym („Polityka” 2016, nr 34)

Zarówno zdjęcie, jak i stanowiący jego graficzną część nagłówek opierają się na zasadzie kontrastu (czyli szerzej: opozycji). Obraz (prawdopodobnie wzięty z repozytorium obrazów, bo nie jest to fotografia dokumentalna) jest oparty na kontraście: pozytyw - negatyw. Właśnie wykorzystany tutaj zabieg techniczny sprawia, że realistyczna fotografia nabiera wymiaru symbolicznego (zauważmy, że nawet same

\footnotetext{
11 Zob. R. Barthes, Światto obrazu. Uwagi o fotografii, tłum. J. Trznadel, KR, Warszawa 1996.

12 T. Piekot, op. cit., s. 125-130.

${ }^{13}$ Ibidem, s. 127.
} 
określenia: pozytyw i negatyw budzą skojarzenia o charakterze oceniającym). Zasada opozycji obejmuje zaróuno pozostałe elementy ikoniczne - tło i kolor czcionki nagłówka wyzyskują kolorystyczny kontrast: biały - czarny (kontrast, któremu róunież jest przypisane wartościowanie), jak i warstwę werbalną. Zdjęciu brakuje podpisu, w relację z nim wchodzi natomiast nagłówek, także formalnie uspółtworzący kolorystyczną i kompozycyjną całość. Zdanie „Zabrać waszym, dać naszym” wyzyskuje opozycję zaimków „wasz - nasz” i czasouników „,,zabrać - dać, podkreśloną jeszcze przez symetrię składniową. W tym wypadku główną funkcję pełni słowo, fotografia jedynie wzmacnia przekaz werbalny - częściowo go dubluje (byłby to przykład na argument paralelny według Roque’a), a dzięki tej redundancji sprawia, że realizowany na dwa sposoby, za pomocą dwóch typów środków semiotycznych komunikat zostaje zauważony i zapamiętany. Werbalny i ikoniczny kontrast uprowadza (ironiczną) ocenę: nasz to dobry (bo na białym tle), wasz to zły (bo na czarnym tle). Lid: „Władza chce stuorzyć nowe społeczeństwo obywatelskie i czuwać nad jego rozwojem. Oznacza to ideologiczną weryfikację organizacji pozarządowych i inny klucz dzielenia publicznych pieniędzy" doprecyzouruje sens nagłówka i nie wchodzi w grę ze zdjęciem.

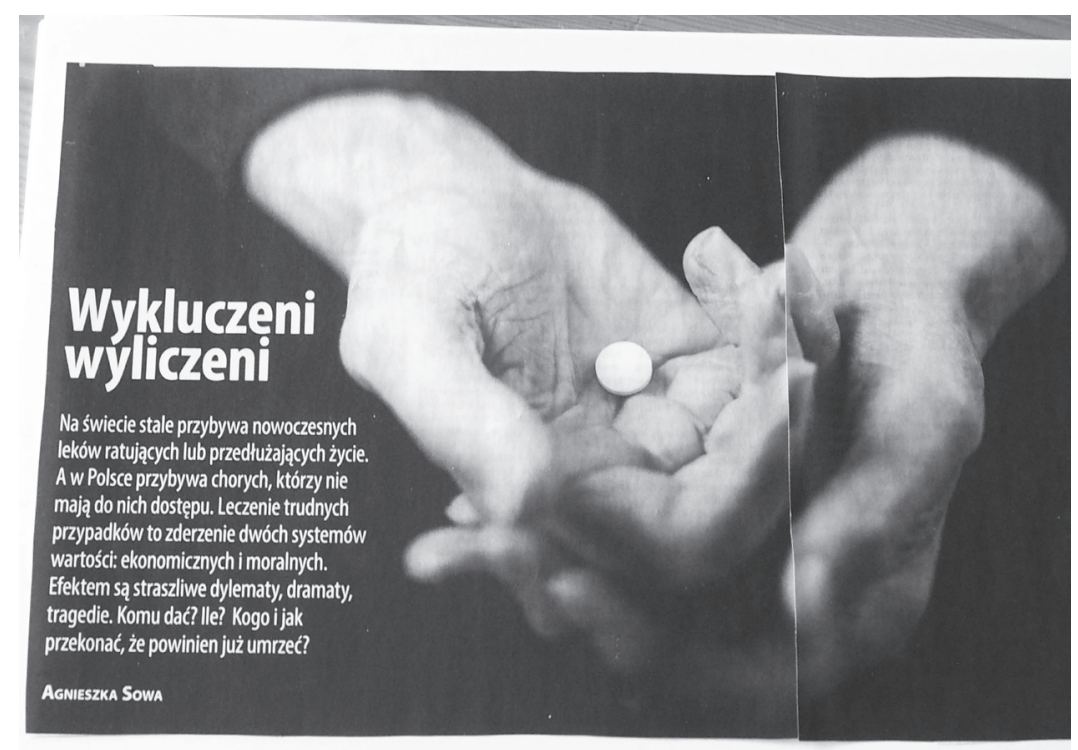

Przykład 3. Artykuł Wykluczeni wyliczeni („Polityka” 2015, nr 38)

Kreowane zdjęcie przedstawia u dużym zbliżeniu dłonie niemłodej osoby (prawdopodobnie mężczyzny), na których spoczywa jedna tabletka. Odnajdujemy tutaj metonimie CZĘŚĆ CIAŁA ZA CZŁOWIEKA (ręce za człowieka) oraz ELEMENT KATEGORII ZA KATEGORIĘ (tabletka za lekarstua). Metonimie te zostały podkreślone za pomocą środków technicznych: sposobem kadrowania (duże zbliżenie) i kolorystyką (jasne ręce na ciemnym tle). Układ rąk sugeruje ochronę otrzymanej cennej rzeczy, 
jaką jest tabletka, kojarzyć się może także z gestem żebraka. Fotografia ta, budząc rozmaite skojarzenia, nie podsuwa jednoznacznej interpretacji. Metonimiczny charakter obrazu każe jedynie zakładać, że będzie to interpretacja symboliczna. Odbiorca, którego uwaga została przyciągnięta przez element ikoniczny, musi w celu jego zrozumienia odwołać się do towarzyszących mu elementów werbalnych: podpisu, nagłówka, lidu. W tym przykładzie podpisu brakuje, a wykorzystujący grę słów nagłówek „Wykluczeni wyliczeni” jedynie przyciąga, ale wydaje się nie mieć związku z obrazem. Dopiero umieszczony na tle zdjęcia lid (nawiązujące do koloru tabletki białe litery na ciemnym tle) uprowadza elementy informacyjne, zakotwiczające (wedle terminologii Barthesa), sugerujące interpretację: „Na świecie stale przybywa nowoczesnych leków ratujących lub przedłużających życie. A w Polsce przybywa chorych, którzy nie mają do nich dostępu. Leczenie trudnych przypadków to zderzenie dwóch systemów wartości: ekonomicznych i moralnych. Efektem są straszliue dylematy, dramaty, tragedie. Komu dać? Ile? Kogo i jak przekonać, że powinien już umrzeć?". I teraz już wiemy, że ręce symbolizują chorego (a właściwie - wszystkich chorych), a tabletka - leki ratujące lub przedłużające życie. Zrozumiały staje się również błagalno-chroniący gest. Fotografia pełni tu przede uszystkim funkcję przyciągającą (pierwszy z typów oddziaływania według Roque’a), a przy tym silnie oddziałuje na emocje, głóunie poprzez sposób kadrowania.

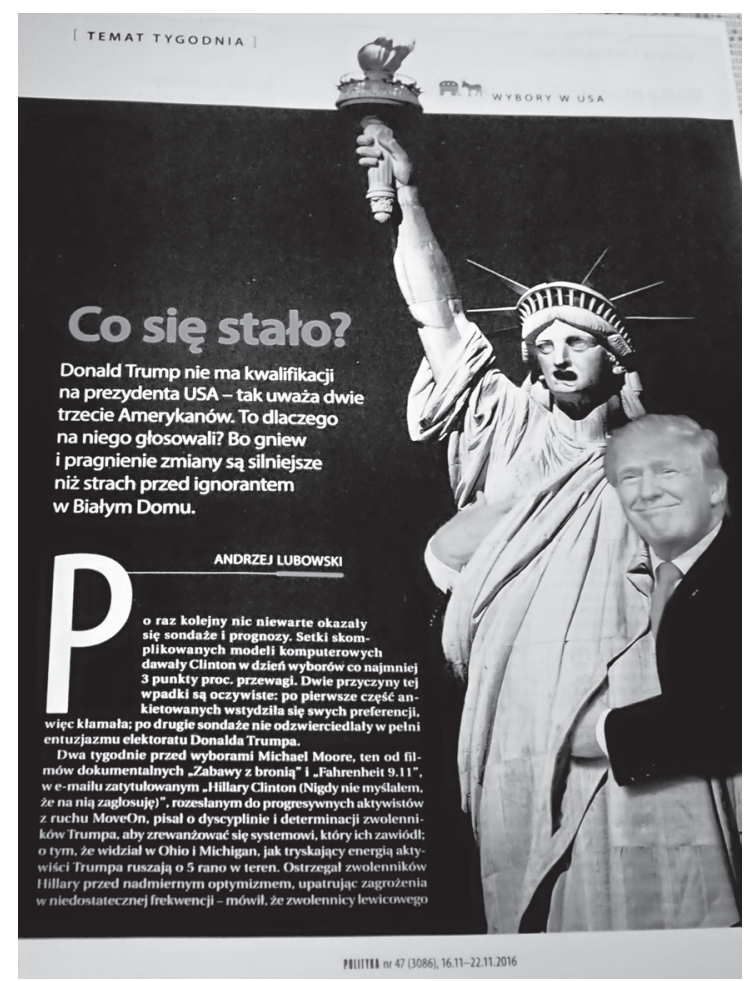

Przykład 4. Artykuł Co się stało („Polityka” 2016, nr 47) 
Jest to przykład fotomontażu, który w „Polityce” (i innych tygodnikach społeczno-politycznych) najczęściej występuje na okładkach. Fotomontaż, jak określa to Kazimierz Wolny-Zmorzyński, jest „świadomą deformacją realnego świata ${ }^{14}$, to sztuczny świat sklejony z realnych części” ${ }^{15}$. Jest suoistą grą z widzem i jak każda gra medialna ma na celu nawiązanie kontaktu z odbiorcą. Ma on wyjątkowo dużą moc przyciągającą (przyciąga przez swoją oryginalność i hybrydyczność) i perswazyjną (oddziałuje przez skojarzenia wywoływane przez jeden czy więcej fragmentów kolażu).

Na prezentowanym obrazie Statua Wolności symbolizuje Stany Zjednoczone, ale równocześnie jest kobietą, którą u sposób dość jednoznaczny obejmuje prezydent Donald Trump. Prowokuje to dwa ciągi skojarzeniowe: polityczny i obyczajowy. W aspekcie politycznym mamy Trumpa, który symbolicznie zdobył (posiadł) Stany Zjednoczone. W aspekcie obyczajouym odczytujemy nawiązania do głośnych obyczajouych skandali i seksistowskich wypowiedzi prezydenta. Ani retoryczne pytanie z nagłówka, ani lid u żaden sposób nie nawiązują do warstwy obrazowej. Ten fotomontaż mógłby właściwie istnieć bez tekstu. Wprowadza on silne nacechowanie emocjonalne i uyraziste wartościowanie. To znakomity przykład, że „Jeden obraz wart/ wyraża więcej niż tysiąc słów".

Przytoczone przykłady pokazały różny sposób funkcjonowania fotografii w tygodnikach społeczno-politycznych. We wszystkich przykładach zdjęcie pełni funkcję przyciągającą, a dzięki temu, że nagłówek jest umieszczony u sąsiedztwie zdjęcia (pod nim, po lewej, na samym zdjęciu) zmusza do jego zauważenia. Również we uszystkich przykładach zdjęcie oddziałuje na emocje i wprowadza wartościowanie. W przykładzie pieruszym i drugim fotografia włącza się przy tym w proces argumentacyjny: ilustruje bądź uzmacnia tezę. W przykładzie czwartym fotomontaż właściwie stanowi samodzielny argument.

Niezależnie od różnych sposobów działania zdjęć wykorzystywanych w tygodnikach opinii widać, jak istotną odgrywają rolę. Trudno już sobie nawet wyobrazić publicystyczny artykuł, który nie byłby opatrzony zdjęciem (lub rysunkiem czy infografiką). Wyrażona w chińskim przysłowiu sprzed wieków zasada „Jeden obraz wart/wyraża więcej niż tysiąc słów" jest realizowana coraz częściej nawet w tych tradycyjnych gatunkach medialnych, które przez wiele lat opierały się przede uszystkim na słowie.

\section{Bibliografia}

Barthes R., Światło obrazu. Uwagi o fotografii, tłum. J. Trznadel, KR, Warszawa 1996.

DuChemin D., Język fotografii. Rozważania o tworzeniu mocniejszych zdjęć, tłum. W. Tkaczyński, Galaktyka, Łódź 2012.

Hill Ch.A., The psychology of rhetorical images [w:] Defining Visual Rhetorics, red. Ch.A. Hill, M. Helmers, Lawrence Erlbaum Associates, Inc., Mayham 2004.

Kampka A., Retoryka wizualna. Perspektywy i pytania, „Forum Ars Rhetoricae” 2011, nr 1.

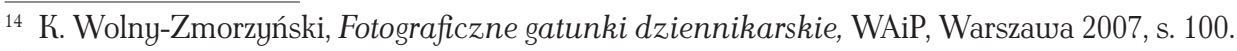

${ }^{15}$ Ibidem, s. 103. 
Michaleuski K., Komunikaty mieszane, Wydaunictwo Uniwersytetu Łódzkiego, Łódź 2009. Piekot T., Dyskurs polskich wiadomości prasowych, TAiWPN Universitas, Kraków 2006.

Roque G., Visual argumentation: a further reappraisal [w:] Topical Themes in Argumentation Theory: Twenty Exploratory Studies, red. F.H. van Eemeren, B. Garssen, Springer Netherlands, Amsterdam 2012.

Skowronek B., Mediolingwistyka. Wprowadzenie, Wydawnictwo Naukowe Uniwersytetu Pedagogicznego, Kraków 2013.

Stöckl H.. Czytanie tekstów językowo-obrazowych? Elementy kompetencji podstawowej [w:] Lingwistyka mediów. Antologia ttumaczeń, red. R. Opiłouski, J. Jarosz, P. Stanieuski, Wrocław-Dresden 2015.

Wolny-Zmorzyński K., Fotograficzne gatunki dziennikarskie, WAiP, Warszawa 2007. 